\title{
TCF12/NR4A3 Fusion Protein
}

National Cancer Institute

\section{Source}

National Cancer Institute. TCF12/NR4A3 Fusion Protein. NCI Thesaurus. Code C99402.

A fusion protein encoded by the TCF12/NR4A3 fusion gene. This protein is comprised of the $\mathrm{N}$-terminus of the transcription factor 12 protein fused to the entire nuclear receptor subfamily 4 group A member 3 protein. 